\title{
TuĞÇE AlKiş
}

Recep Tayyip Erdoğan University

(iD https://orcid.org/0000-0003-2637-2630

\section{Deciphering the Self and the World Through Fantasy in Neil Gaiman's Coraline}

\begin{abstract}
The aim of this paper is to show how contemporary children's fantasy fiction offers alternative methods to children and teenagers for confronting real-life issues, such as self-discovery, sense of belonging and the process of individuation, through the analysis of Neil Gaiman's Coraline. In his contemporary children's fantasy book, Gaiman empowers his protagonist to explore her sense of self, overcome her insecurities and fears in a fantastic mirror-like home. This paper argues that fantasy is an effective device for explaining the complexities and dilemmas of the self and examining a child's quest for self-discovery in the process of maturation and individuation.
\end{abstract}

KEY WORDS: self-discovery, individuation, sense of belonging, mirror-like home, fantasy

"People who deny the existence of dragons are often eaten by dragons."

Ursula K. Le Guin, The Wave in the Mind

Contemporary children's fantasy fiction empowers children and teenagers to seize their own paths in order to construct their sense of self. It mirrors their real concerns, problems, needs, wishes and demands, instead of just portraying the extraordinary and the magical. Most writers of children's fantasy fiction, like Philip Pullman, J. K. Rowling and Neil Gaiman have used fantasy as a mirror, "reflecting a recognition that the problems of the 'real world' extend to its representation" (WebB, 2015: 2). For example, J. K. Rowling's Harry Potter series and Philip Pullman's trilogy, His Dark Materials, both delve into the real concerns and problems of child protagonists in their quest for self-discovery. Furthermore, these books, like most contemporary examples of children's fantasy fiction, highlight that childhood is not a trouble-free stage of life, because childhood and adolescence are the phases of ambiguities, dilemmas, imbalances, emotional 
upheavals and psychological transformations. Similar to Harry in Rowling's series and Lyra in Pullman's trilogy, Coraline in Gaiman's book gains a fresher perspective about emotional conflicts and the difficulties of growing-up through the challenges of her fantastic journey.

As a prominent work of contemporary children's fantasy fiction, Gaiman's Coraline explores real issues like self-discovery, sense of belonging and the process of individuation. It depicts the story of a young female protagonist whose sense of loneliness and boredom directs her to explore a mirror-like home where her life is duplicated in a twisted way. An eerie simulacrum of her house embodies her fears, anxieties, concerns and desires. Throughout the book, Gaiman employs fantasy to enable both Coraline and young readers to speak out about their expectations and views, confront their repressed feelings and find their hidden pieces to solve the puzzles of their identities. In this respect, this study examines how fantasy functions as an alternative and effective device for children in the discovery of the self and the process of individuation, and in facing the challenges and difficulties of real life.

Neil Gaiman intertwines fantastic details with ordinary ones in order to establish a link between the threatening atmosphere of the fantastic world and the dangers and difficulties of the real world. The intersection between the real home and the fantastic one centres on Coraline's journey of gaining awareness both about herself and her environment. The mirror-like home, which reminds the readers of the upside-down world of Wonderland and the Looking-Glass house, reflects Coraline's fantastic and fearsome adventures with dehumanised versions of her real parents, anthropomorphised animals and grotesque neighbours. Just like Alice, Coraline tries to find the answer to the question of self-discovery: "Who in the world am I?" (CARroll, 2001: 46). This question is "the great puzzle" (46) for all children in the process of maturation. However, it is also the starting point for them to broaden their perspectives both about themselves and the world. This kind of challenging questions and struggles throughout the journey of self-discovery is the essence of children's fantasy fiction, just like in Coraline.

As a story of maturation, Coraline employs fantasy as an effective vehicle to analyse the challenges of the youth while they struggle to construct their sense of self and identity. M. O. Grenby states that:

Fantasy is extremely well suited to consideration of questions of identity. The journey to another world, or another time, decontextualises the protagonists, removing them from the structures that locate and bind them into a particular role within the family, the school, or the larger society. They then have to discover afresh who they are, and, usually, can return to their reality at the end of the novel with a stronger sense of themselves. Perhaps this helps to explain why children's fantasy has become increasingly prevalent. (2008: 164) 
In a similar way, Gaiman draws attention to the ordinary problems and concerns of children and teenagers, such as belonging to family, school and environment, transporting his story into a fantastic world. Coraline struggles to adapt herself to her new home and its neighbourhood. Additionally, she tries to figure out how her relationship changes as she grows up. To gain a refreshed perspective about the challenges of daily life, Coraline needs an alternative route. Therefore, Gaiman "cast[s] the entire process into a fantasy narrative where, despite difficulties, the protagonist achieves [...] her goal, the psychic need for venture and reassurance is satisfied; the journey [isn't] easy, and in fact it [is] quite fearsome. But [she] find[s] the strength, wit" (COATs, 2018: 354). Gaiman directs his protagonist into a threatening and challenging fantastic journey to both provide a self-awareness to Coraline and to show the reader how children and teenagers are haunted by their fears, concerns and problems. In children's fantasy fiction, as Coats asserts, "[t]he dark landscapes, [...] villains correspond to the dangerous impulses and aggressions that children actually experience as part of their own mental topographies" (2009: 78). Therefore, the embodiments of Coraline's fears, desires and hesitations in the fantastic world of mirror-like home provide a wider understanding for her to reconcile with the complexities and dilemmas in the face of the difficulties and problems of the real world.

Gaiman subverts the traditional notion that childhood is a sanctuary shielded from the difficulties of the adult world. Rather than portraying a peaceful atmosphere similar to the one in A. A. Milne's Winnie the Pooh books, he riddles his story with scary and discomforting details. Jerome Griswold emphasizes that:

Adults, in my experience, don't like to have pointed out to them that childhood is a very scary time and the world of Children's Literature is a very scary place. Forgetting their own childhoods, many grown-ups prefer a sentimental notion of childhood, where [...] the sun is always shining. In a similar way, adults often have a saccharine notion of Children's literature as sweet and cute. (2006: 31)

While Gaiman validates that childhood is not exempt from fears, anxieties, and insecurities, adults often consider these feelings temporary and simple. Coraline, who struggles with the emotional turbulences of growing-up, is invited into a mirror-like home that seems to promise shelter. However, once she crosses the threshold, she finds herself truly left alone to defeat her fears and anxieties in a creepy simulacrum of her home. While Neil Gaiman's story could be terrifying for younger children, his intention is apparently not to scare them. Instead, he seeks to remind his readers that children and teenagers do not have a button that they can press to immediately delete their concerns and fears. The path to adulthood is scary and full of challenges as childhood is left behind. However, 
these challenges make them braver and more confident when it is time for them to take on the responsibilities of the adult world.

Neil Gaiman tells his story through the eyes of a preadolescent girl about to embark on the emotional upheavals and instabilities of adolescence. Although Gaiman does not define Coraline's age throughout the story, she appears to be eleven or twelve years old. When the story begins, Coraline and her family have just moved into a flat in a very old house. The gothic structure of the house is mysterious and encourages her to explore. However, this also makes it difficult for her to construct any sense of belonging to the new place. In addition to her new surroundings, Coraline also feels ignored by her parents, who are generally too busy with their own work at home. For example, when she has to stay inside on a rainy day, she gets bored and asks her mother what she can do. Her mother's suggestions are to "[r]ead a book, [...] [w] atch a video, [p]lay with your toys. Go and pester Miss Spink or Miss Forcible, or the crazy old man upstairs" (Gaiman, 2013: 6). None of these are satisfactory for Coraline and she says, "I want to explore" (6). Her mother's response to her demand is that "I don't really mind what you do [...] as long as you don't make a mess" (7). Unable to draw her mother's attention, she turns to her father and tries to get permission to go out, and instead he suggests, "explore the flat" (8), which is also not satisfying for Coraline. Her parents, most of the time, work on their computers at home and it seems they do not have enough time to take care of Coraline's requests. She wants to make her needs and desires seen and she wants her parents to care about them. Her desire to explore the outside - even if it does not seem secureemphasizes her path to individuation. However, she still needs her parents' support and affection.

Gaiman portrays a modern family and their attitudes in child upbringing, but he problematizes the situation for Coraline because his book "is centrally concerned with how one negotiates one's place in the world; how one is recognised in one's own either ignored on the one hand, or stifled on the other" (RUDD, 2008: 160). However, it is not clear whether the problem is that Coraline's parents neglect her needs or that Coraline looks at her life in a mirror, which distorts reality. Although it seems that Coraline, with her egocentric viewpoint, exaggerates her parents' indifference to her demands and desires, Gaiman reveals that a child always desires to make her/his needs visible to her/his parents. Coraline, who is on the verge of adolescence, bears a lot of hesitations about herself and her family. Among her imbalances and insecurities, she likely just focuses on what she deems negative traits of her family.

Her lack of satisfaction with her parents also circles around the gendered stereotypes of male supremacy. Her perception seems to stick to the binary oppositions between the roles of male and female. However, her parents share the responsibilities of home equally, without domesticating the mother figure. For example, her mother goes shopping while her father prepares the meal. From 
Coraline's perspective, her mother prefers the easiest way to cook while her father cooks meals with his creative recipes. She is not pleased with the meals her father prepares; instead, she prefers convenience food like pizza and chips. Even though her mother sometimes makes chicken, she still does not like it. The seemingly exchanged gender roles of father and mother figures oppose the way society has portrayed a traditional family. Coraline seeks the domesticity of a traditional family where the mother is the essential figure of nurturing care for a child. Therefore, "[t]he lack of food at home and her hasty solution to the problem of providing lunch for her daughter-signs of her failure as a mother according to conventional domestic ideals-open Coraline to the other mother" (KeEling and Pollard, 2012: 11), who seems to fulfil the domesticity of a traditional family. Coraline's dissatisfaction with the meals depicts her misconceptions of gender roles, as ruled by patriarchal law. It also shows how her ideals and expectations can be manipulated, because she has not yet discovered her authentic perception of herself and the world around her. Throughout Coraline's maturation journey, Gaiman contrasts Coraline's real parents and the other parents in order to enable Coraline to question the established norms, such as the domesticity of home and mother, the notion of the idealization of a family and the traditional gender roles of parents.

Coraline, as a coming-of-age story, presents a world in which there is no easy path to follow and the protagonist needs to be an explorer in order to reformulate her true and reliable sense of self and identity. Coraline defines herself as an explorer and she repeats her desire to explore throughout the novel. From the very beginning, Gaiman acknowledges that his story is a quest for self-discovery. The book opens with Coraline finding a door in her new house. She immediately becomes curious about this door in the drawing room, which becomes a bridge between her real world and the duplicated fantastic one. She has to cross this threshold to re-evaluate her expectations, hesitations and dilemmas. At the beginning, this door is blocked by a brick wall because she is not ready to follow the path to growing-up. The brick wall represents the border between childhood and adulthood. The conversation that she has with her mother about the door also serves as a powerful illustration of the difference between an adult and a child:

She said to her mother, 'Where does that door go?'

'Nowhere, dear.'

'It has to go somewhere.'

[...] She unlocked the door with the key. The door swung open. Her mother was right. The door didn't go anywhere. It opened on to a brick wall. [...] 'You didn't lock it,' said Coraline.

Her mother shrugged. 'Why should I lock it?' she asked. 'It doesn't go anywhere.' 
Her mother evaluates the situation with concrete truths, but Coraline does not accept these rigid truths, because a "child always seeks and therefore always sees more" (LEE, 2016: 557-558). Neil Gaiman contrasts the profoundness of a child's imagination with an adult's identification with tangible entities. He emphasizes that the intensity of childhood imagination and wonder is a key to opening doors to fantastic adventures. Coraline's imagination, wonder and curiosity are her guidance in gaining self-awareness and for this, Gaiman's effective tool is fantasy, which "enables us to enter worlds of infinite possibility. The maps and contours of fantasy are circumscribed only by imagination itself" (MATHEws, 2002: 1). Thus, the door as a threshold to Coraline's quest for self-discovery is the initiator of her fantastic journey.

With the events that happen the night after Coraline's conversation with her mother, Gaiman prepares both his protagonist and the young readers for her peculiar quest. First, Coraline suspects that she sees "a thin giant woman" (11) and checks the door, but there is still a brick wall there. Then, she has a nightmare in which "[1]ittle black shapes with little red eyes and sharp yellow teeth [...] sing: We are small but we are many/[...]/[..]/We will be here when you fall" (12). Although these creatures have a message for Coraline not to "go through the door" (19), the song - which she hears again after she enters the other mother's world - appears as an invitation to that fantastic world. Gaiman paves the road for Coraline's difficult and dangerous but necessary journey, so that she can reshape her assumptions about herself and her family. He deliberately directs Coraline to an unknown environment and new routes, because the path to growing-up is labyrinthine but inevitable. Her entrance into the fantastic world behind the door functions as a metaphoric fall; it is a transition from inexperience to experience. Just like Alice, Coraline should fall down the rabbit hole and enter the looking-glass house in order to cope with her fears, anxieties and to construct her authentic sense of self and identity. Instead of sanctifying childhood with the illusion of Neverland "in which the protagonist refuses the opportunity to move forward from childhood" (HouriHan, 1997: 166), Gaiman chooses to examine the metaphoric fall by having his protagonist confront it. Even though growing-up is frightening, "it isn't all gloom. There is a prize" (Pullman, 2017: 48). Growing-up is "like discovering a new continent - new forms of knowledge, new ways of understanding, immense vistas of possibility" (47). Therefore, Gaiman, like most writers of contemporary children's fantasy fiction, empowers Coraline to make her own decisions and follow her own paths after gaining experience through the challenges of the fantastic world.

Coraline shows the reader that the path to construct a true sense of self and the process of individuation demand finding one's own voice which distinguishes them from others and provides self-esteem. For example, Coraline's mother asks her to draw something and she decides to draw a mist. However, instead of drawing it, she writes the word in capital letters, without the letter $I$, which 
she writes on the next line. On the one hand, the word "mist" without the letter $I$ symbolizes the fact that Coraline's sense of self is still clouded with illjudgements and doubts about herself and the world. Thus, the letter $I$, which represents Coraline's sense of self, cannot complete the word. On the other hand, the letter I, which stands by itself and does not complete the word "mist", signifies Coraline's desire to uncover her invisibility to her family and her move towards individuation. Furthermore, when she goes to buy school clothes with her mother, she wants to have Day-Glo green gloves which none of the other students have at school. Coraline desires to be distinguishable from others and wants to be noticed by other people, like her family. Generally, when she cannot attract her parents' attention, she begins to ask questions about the door or the empty flat behind the door: "Do you think you could get into it from our flat?" (Gaiman, 2013: 30), to which her mother responds: "Not unless you can walk through bricks, dear" (31). Thus, her mother's unsatisfactory explanation leads her to investigate beyond the seen and the known.

In her boredom and disappointment with her parents, she appears to long for adventures in which she can fulfil her wishes and unmet needs. While her mother repetitively tells Coraline that it is impossible to cross the other flat through the door, she does not give up the search for a way to enter the empty flat. Although her mother proves that the door is blocked by a brick wall, Coraline still controls the existence of the brick wall. She practices this control frequently when her parents are not around. She secretly gets the key and unlocks the door when her mother goes to the supermarket. This time, the door "open[s] on to a dark hallway" (33); the brick wall is not there. This shows one of the distinguishing characteristics of children's fantasy fiction that generally distances children from the control of parents in the process of their individuation. Although "[c]hildren are dependent on their parents, physically and emotionally, [...] part of growing up involves liberation from parental protection" (NikOLAJEVA, 2005: 75). For Coraline, the first step in this process is that she can enter the other home only in the absence of her parents. Then, her quest for self-discovery starts when she enters the fantastic mirror-like world of the other mother:

The carpet beneath her feet was the same carpet they had in their flat. [...] She knew where she was: she was in her own home. She hadn't left. [...] She stared at the picture hanging on the wall: no, it wasn't exactly the same. The picture they had in their own hallway showed a boy in old-fashioned clothes staring at some bubbles. But now the expression on his face was different - he was looking at the bubbles as if he was planning to do something very nasty indeed to them.

(GaIman, 2013: 33)

The other home is like a mirror. At first everything looks the same, but then Coraline realizes that there are some differences. As Greer Gilman says, 
"[m]irrors are uncanny. In reflecting, they estrange. The object in the mirror ought to be the object mirrored; yet it is not" (2015: 141). This mirror-like home both reveals her otherness to herself and distorts her perception of reality. When Coraline hears the other mother's voice, it is similar to her mother's voice, but her appearance is quite different from her real mother's appearance. The other mother's eyes are big black buttons and the other father's eyes are the same. While the other mother is preparing the best chicken Coraline has ever tasted, the other father is studying in his room. Gaiman centralizes the main contrast between the two families as providing satisfactory food for Coraline, because one of the most significant duties of family is to nurture. The other mother seeks to impress Coraline and thus she initiates this process by portraying herself as an affectionate caregiver who provides delicious meals. The other parents seem to represent gender stereotypes of a traditional family, whereas Coraline's own parents fail to perform the desired features of an idealized family. The other mother tells her "in a voice so close to her real mother's that [...] 'We're here. We're ready to love you and play with you and make your life interesting" (Gaiman, 2013: 70-71). These affectionate words are exactly the ones that Coraline wants to hear from her real parents.

Although, at first, the other mother's world seems to be an extension of Coraline's desires and needs, she starts to feel uncomfortable as she explores more and the situation gets stranger. Her other bedroom is decorated more luxuriously than her bedroom and she has a "whole toybox filled with wonderful toys" (37). However, she does not feel like she belongs there, most probably because the other room does not reflect her individual taste and habits. The crucial moment for Coraline is when the other father says that "[t]here's only one thing we'll have to do, so you can stay here for ever and always" (53). This little thing is that they want to sew big black buttons, like the ones they have, onto her eyes. These black button eyes are actually the embodiments of the other mother's authority and her panopticon gaze. As Rudd points out, "Coraline's button replacements have the related association of giving up one's soul, the eyes being its windows" (2008: 163). The acceptance of these black button eyes symbolizes the submission to the other mother's surveillance. The other mother's black button eyes also enable her to hide her emotions and thoughts. Thus, Coraline cannot be sure when and where the mother monitors her. As Coraline says, "if she were nowhere, then she could be anywhere. And, after all, it is always easier to be afraid of something you cannot see" (GaIman, 2013: 113). At the very beginning, the other mother pretends to fulfil the conventional maternal role as a nurturing mother in order to manipulate Coraline. In an effort to play into Coraline's insecurities, the other mother tries to deceive her with a mirror illusion. Coraline looks at her parents being happy without her, and hears her real mother say, "How nice it is, not to have Coraline any more" (73), and her father adds, "I take great comfort that in knowing that her other mother will take bet- 
ter care of her than we ever could" (73). Coraline is deceived to believe that her real parents are fed up with her. Gaiman prefers that his protagonist confronts her repressed fears and anxieties in a fantastic world, because fantasy can function as "the language of the inner self" (LE GUIN, 1975: 148), and an alternate expression or verbalization of all these repressed emotions. Michael Howarth states that:

Children have many fears. Two of the most common are the fear of being abandoned and the fear of being overpowered. [...] The best children's books address both of these natural fears. Rather than simply scaring children and making them feel foolish and ashamed, these books respect children enough to validate their anxieties, and they present absorbing stories that engage children's attention and give them new ideas and viewpoints to consider. (2014: 11)

Coraline has these overwhelming fears, one of which is reflected in the mirror in the other mother's world. Although at first, the other home looks like the ideal place for her, it turns into a nightmarish space where she is trapped by the other mother's power. The other neighbours and even the other father become the puppets of the other mother's hegemony. For instance, the copy of her neighbour, Mr. Bobo, tries to convince Coraline to stay, by saying that "Nothing's changed. You'll go home. You'll be bored. You'll be ignored. No one will listen to you, not really listen to you" (GAIMAN, 2013: 142). Gaiman creates a fantastic world which is ruled by the other mother. This juxtaposition gives Coraline an opportunity to make comparisons between her own home and the other mother's creepy and disturbing place. In this respect, Gaiman also emphasizes the differences between parenting styles. While Coraline's real parents enable her to explore and take responsibilities on her own, the other mother orders Coraline to be completely dependent on her and requires her to strictly obey her demands. With this contrast, Gaiman underlines that home or family becomes a nightmare for children if they are manipulated by excessive power and control. When the other parents talk to her about getting the buttons, the other mother says "We only want what's best for you" (54). However, it is not about Coraline, but what is best for the other mother. Although Coraline refuses the black button eyes and returns to her own home, the other mother forces Coraline to come back to her by kidnapping her real parents. At first, she does not realize that her family has been kidnapped by the other mother. Since the absence of her parents is not out of character, she just takes care of herself; she microwaves pizza, goes to the supermarket, and takes a bath. All these highlight that her real parents have taught her how to care for herself and take responsibility.

The other mother only wants Coraline to be submissive to her authority and thus the more Coraline fights against the other mother's authority, the crueller 
the other mother becomes. After Coraline returns to the other home, the other mother imprisons her in a mirror under the pretext of making her "ready to be a loving daughter" (93). In this mirror, she encounters three children whose hearts and souls have already been stolen by the other mother. This incident makes it clear that the other mother's main aim is to subordinate everyone to her authority and that any refusal of her authority results in punishment. With the expectation that Coraline has learned a lesson from her punishment, the mother allows her to leave the prison of the mirror. Although the other mother still tries to deceive her by pretending to be a loving and nurturing caregiver, the punishment and imprisonment make her cruelty obvious to Coraline. Instead of being a loving maternal figure, she also plays the role of the patriarchal father who dominates, tries to pacify her husband and endangers the freedom and individuation of children. Coraline becomes aware that the other mother's so-called love is an indicator of her obsession with control. Additionally, she realizes that the conventional gender roles are not the assurance of a happy family, because when the other mother can no longer trick Coraline, she reveals her monstrousness like the witch in "Hansel and Gretel".

Coraline's realization of the other mother's deception makes her struggle against authority and control. She puts on her own clothes by taking off the clothes the other mother gave her, she takes an apple from her own home to avoid the other's delicious meals. These small details emphasize her process of individuation. In the absence of parental or adult guidance, Coraline is helped by a cat that accompanies her on her fearsome adventures. When Coraline wants to play with this cat in the real world, it disappears. Like in most children's fiction, Coraline has a fellow animal in the absence of parental care and support. As a mentor, the cat advises her to play a game with the other mother. Its suggestion to Coraline is to "[c]hallenge her. There's no guarantee she'll play fair, but her kind of thing loves games and challenges" (76). Games subvert the unequal power relations between a child and an adult. Therefore, Coraline can use a game to trick the other mother into defeat, saving herself. They make a deal that if Coraline wins the game, she can rescue her parents and the trapped children. However, if she loses, she has to live under the control of the other mother. The other mother's abduction of Coraline's parents exemplifies her purpose of blocking Coraline's path to maturation because growing-up consists of the realization of her individual identity and her sense of authentic self. While her own parents symbolize independence and individuation, the other mother expresses the entrapment under the power of authority. As Holly Virginia Blackford remarks, "Other mother's attempts to lock Coraline into childhood suggest attempts to ground the child and forestall the assertions of the adolescent" (2012: 209). Coraline struggles between leaving childhood and experiencing adolescence. Therefore, her changing emotions and thoughts are indicators of her emotional upheavals and preadolescent insecurities. The journey to defeat the other mother 
is a path of overcoming her insecurities about growing up and exchanging her ill-judgments about her parents with the good ones. While fighting against the authority of the other mother, she remembers a moment when her real father taught her how to be brave even though she feels scared.

In the process of individuation and maturation, Coraline creates her own monster by projecting her fears and anxieties onto the other mother figure. The other mother represents her externalized self. As David D. Gilmore points out, "The mind needs monsters. Monsters embody all that is dangerous and horrible in the human imagination. Since earliest times, people have invented fantasy creatures on which their fears could [...] settle" (2003: 1). The more fears and anxieties become ambiguous, the more they become fearsome and unmanageable for children. When they embody tangible forms, it is more feasible to find ways to defeat them. Coraline's emotional turbulences are so overwhelming for her that the self is fragmented into an imaginary monster created to reconstruct her rationalized self. As Bettelheim says, "Once the child's inner pressures take over-which happens frequently - the only way [s/]he can hope to get some hold over these is to externalize them" (1991: 65). It is also common for children to create their imaginary doubles or characters, especially when they play alone. Coraline, in her boredom and loneliness, creates her own playground where she questions whether there is "an other Coraline" (82) and she meets the imaginary doubles of her parents and neighbours. At first sight, these doubles seem to be directed by her desires and wishes until the other world becomes haunted by her fears and anxieties. However, Coraline's repressed and hidden feelings-even if they are unwanted - need to be unmasked. Gaiman employs fantasy to unearth Coraline's complexities and struggles in her ordinary life. Thanks to the fantastic world, Coraline can distance herself from her misassumptions about her parents and her environment and can face her insecurities and repressed feelings to be able to reconstruct her sense of self.

Gaiman enables Coraline to be brave and aware of the traps and difficulties of real life. Her fantastic journey refers to a psychological experience and is a quest for self-exploration. In this journey, she refuses to obey the other mother's authority and thanks to her courage, she rescues her family and the trapped children. She actually becomes the saviour of her life by correcting her false assumptions about her sense of self, her identity and her family. After she returns to her home, almost everything is different for her. She can tolerate most of the things she complained about beforehand. She appreciates her family and she understands that her family does not ignore her, but instead they want her to explore the world around her without making her feel controlled. On her road to maturation, she can distance herself from her egocentric viewpoint. In other words, Gaiman employs fantasy as "cleansing of our eyes so that we can see our world more clearly" (JAMES, 2012: 66), and encourages young readers to "do enjoy accompanying her on [her fantastic journey] because they are able to learn 
from their mistakes and also to relate her predicaments to those same dilemmas they often experience in their own lives" (HowARTH, 2014: 84).

Gaiman's contemporary children's fantasy book portrays the uncertainities of children and teenagers without belittling them. In Coraline, he utilizes fantasy to demonstrate the insecurities of the young about themselves and the world. His story illuminates that fantasy "is a journey into the subconscious mind [...], it can be dangerous; and it will change you" (Le GuIN, 1989: 80). Fears, anxieties, complexities and dilemmas are part of human mind and life. Therefore, it is important for both children and teenagers to learn how to live with them, in order not to let them haunt their lives. In Coraline, Gaiman shows that "The horizons of contemporary children's literature are much wider, and the world of childhood is no longer secluded and protected" (NiKOLAJEVA, 2005: 139), and that fantasy is a prominent method to examine the psychological upheavals and insecurities of children and teenagers in their quest for self-discovery. Thus, Coraline suggests alternative perspectives for young readers to remove baobabs which endanger their inner self and to differentiate them from rose bushes which guide them into their authenticity. Gaiman's story encourages them to tear down the walls which block their roads to maturation and individuation and be brave enough to explore the unknown and believe in their power of imagination.

\section{Bibliography}

Bettelheim, Bruno, 1991: The Uses of Enchantment: The Meaning and Importance of Fairy Tales. London: Penguin Books Ltd.

Blackford, Holly Virginia, 2012: The Myth of Persephone in Girls' Fantasy Literature. New York: Routledge.

Carroll, Lewis, 2001: Alice's Adventures in Wonderland \& Through the Looking-Glass. Hertfordshire: Wordsworth Editions Limited.

COATs, Karen, 2009: "Between Horror, Humour, and Hope: Neil Gaiman and the Psychic Work of the Gothic". In: The Gothic in Children's Literature: Haunting the Borders. Ed. Anna JACKSON, Karen COATS, and Roderick McGILLIS. New York: Routledge, 77-92.

CoAts, Karen, 2018: The Bloomsbury Introduction to Children's and Young Adult Literature. London: Bloomsbury Publishing Plc.

Gaiman, Neil, 2013: Caroline. London: Bloomsbury Publishing Plc.

Gilman, Greer, 2015: "The Languages of the Fantastic". In: The Cambridge Companion to Fantasy Literature. Ed. Edward JAmes and Farah Mendesohn. Cambridge: Cambridge University Press, $134-146$.

Gilmore, David D., 2003: Monsters: Evil Beings, Mythical Beasts, and All Manner of Imaginary Terrors. Philadelphia: University of Pennsylvania Press.

Grenby, Matthew O., 2008: Children's Literature. Edinburgh: Edinburgh University Press Ltd.

Griswold, Jerome, 2006: Feeling Like a Kid: Childhood and Children's Literature. Baltimore: Johns Hopkins University Press. 
Hourihan, Margery, 1997: Deconstructing the Hero: Literary Theory and Children's Literature. New York: Routledge.

Howarth, Michael, 2014: Under the Bed, Creeping: Psychoanalyzing the Gothic in Children's Literature. North Carolina: McFarland \& Company, Inc.

JAmes, Edward, 2012: "Tolkien, Lewis and the Explosion of Genre Fantasy". In: The Cambridge Companion to Fantasy Fiction. Ed. Edward James and Farah Mendlesohn. Cambridge: Cambridge University Press, 62-78.

Keeling, Kara K. and Scott Pollard, 2012: "The Key Is in the Mouth: Food and Orality in Coraline". Children's Literature, vol. 40, 1-27.

LeE, Derek, 2016: "The Politics of Fairyland: Neil Gaiman and the Enchantments of Anti-Bildungsroman". Critique: Studies in Contemporary Fiction, vol. 57, no. 5, 552-564.

Le Guin, Ursula K., 1975: "The Child and the Shadow". The Quarterly Journal of the Library of Congress, vol. 32, no. 2, 139-148.

Le Guin, Ursula K., 1989: "From Elfland to Poughkeepsie". In: Idem: The Language of the Night: Essays on Fantasy and Science Fiction. London: The Women's Press Ltd., 70-82.

Le Guin, Ursula K., 2004: The Wave in the Mind: Talks and Essays on the Writer the Reader, and the Imagination. Boulder: Shambhala Publication, Inc.

Mathews, Richard, 2002: Fantasy: The Liberation of Imagination. New York: Routledge.

Nikolajeva, Maria, 2005: Aesthetic Approaches to Children's Literature: An Introduction. Maryland: Scarecrow Press, Inc.

Pullman, Philip, 2017: "Heinrich von Kleist: On the Marionette Theatre: Grace Lost and Regained”. In: Daemon Voices: Essays on Storytelling. Ed. Simon Mason. Oxford: David Fickling Books, 45-52.

RudD, David, 2008: "An Eye for an I: Neil Gaiman's Coraline and Questions of Identity". Children's Literature in Education, vol. 39, 159-168.

WebB, Caroline, 2015: Fantasy and the Real World in British Children's Literature: The Power of Story. New York: Routledge.

\section{Bio-bibliographical note}

Tuğçe Alkış received her B.A. from the department of English Language and Literature at Atatürk University, Turkey in 2009. She then completed her M.A. in the same department at Istanbul University in 2014 and her PhD at Atatürk University in 2020. She works as a research assistant at Recep Tayyip Erdoğan University, Turkey.

tugcealkis@hotmail.com 